\author{
WOJCIECH LEMAŃSKI \\ (D) https://orcid.org/0000-0003-1441-2631 \\ Uniwersytet Śląski w Katowicach \\ Katowice
}

\title{
Czy męskie kobiety i zniewieściali mężczyźni to wytwór kultury współczesnej? Ślady przenikania się ról płciowych w dramacie Barbara jeszcze Gasztołdowa żona Dominika Magnuszewskiego
}

Are masculine women and effeminate men a product of contemporary culture?

Traces of gender role interpenetration in Dominik Magnuszewski's play Barbara jeszcze Gasztołdowa żona

\begin{abstract}
The aim of the paper is to show the social and cultural processes that perpetuate the patriarchal model of society using the example of Dominik Magnuszewski's play Barbara jeszrze Gasztołdowa żona. Using research in the field of cultural anthropology, I consider the work in the context of the representation of gender roles in a manner inconsistent with the archetypal patterns. King Sigismund represents the type of effeminate masculinity, while Queen Bona is referred here to the virago femininity type, combining traits considered as masculine and feminine. The paper develops research into the problem of the domination of patriarchy in 19th century Poland, using terminology taken from cultural anthropology (androcentric ignorance).
\end{abstract}

Keywords: Dominik Magnuszewski, Romanticism, women in history and literature, androcentric ignorance

Twórczość Dominika Magnuszewskiego obfituje w interesujące reprezentacje relacji damsko-męskich. Cykl utworów Niewiasta polska w trz̨ech wiekach z roku 1843 przedstawia historię polskich kobiet na przestrzeni dziejów, odnosząc się do takich wydarzeń, jak: wyprawa Bolesława Śmiałego na Ruś Kijowską w Krwawym chrzcie roku 1074, burzliwa miłość Barbary Radziwiłłówny i Zygmunta Augusta w Barbarze jeszcze Gasztoldowej żonie czy insurekcja kościuszkowska w ostatnim utworze pt. Posiedzenie Bacciarellego malarz̧a. Już 
przed powstaniem Niewiasty Magnuszewski interesował się tematyką historyczna, a w jego dorobku można odnaleźć ciekawe spostrzeżenia na temat płci. Przykładem jest dramat Radriejowscy, którego akcja została osadzona w roku 1656, a w którym pojawia się postać „rycerza-dziewicy”, przypominająca Graj̇yne Mickiewicza czy Lenore Bürgera (Ruszczyńska 1995, 81).

Pierre Bourdieu w książce Męska dominacja pisal, że:

istniejący porządek $z$ wpisanymi weń relacjami dominacji, prawami i krzywda, przywilejami i niesprawiedliwością utrwala się tak łatwo (wyłączając kilka historycznych przypadków); że trudne do zniesienia warunki egzystencji traktowane sa jako akceptowalne, a nawet naturalne (Bourdieu 2004, 8).

Badając społeczność Berberów kabylskich, Bourdieu podchodzi do problemu męskiej dominacji w kulturze z perspektywy etnograficznej i widzi w nim narzędzie „socjoanalizy androcentrycznej nieświadomości” (Bourdieu 2004, 14). Stwierdza, że takie archaiczne praktyki, jak postrzeganie świata poprzez ciało czy podstawowe opozycje: mokry - suchy, krótki - długi, pod - nad, przekładają się na utrwalanie męskiej percepcji świata nie tylko przez mężczyzn, ale przez całe społeczeństwo. Na podstawie tych zależności wytworzyła się kultura oparta na nieświadomym odbieraniu rzeczywistości z męskiej perspektywy.

Powyższą obserwację można zastosować w badaniu relacji damsko-męskich w utworach literackich, prezentując pewien zespół praktyk utrwalających typowo „męski” porządek świata. Te obserwacje stanowią podstawę mojej analizy dramatu Magnuszewskiego Barbara jeszcze Gasztołdowa żona.

Ważnym aspektem, w którym objawia się patriarchat w tym utworze, jest kreacja postaci księcia Zygmunta Augusta, percypowanego przez innych mężczyzn jako zniewieściałego. Na podstawie Męskiej dominacji Bourdieu można stwierdzić, że „ukobiecanie” mężczyzn jest dla nich degradujące i ma negatywny wpływ na męskie wartości, takie jak honor czy cnota (Bourdieu 2004, 32). Co więcej, osoby zniewieściałe są źle postrzegane w roli władcy, ponieważ zbliżają się do kobiecego wzorca, będącego niereprezentatywnym dla władzy w rozumieniu ogólnym.

Androcentryzm jest pojęciem, które oznacza, że społeczeństwo i jego wytwory odzwierciedlają doświadczenie męskie, a męską percepcję świata uznaje się za uniwersalną. Tłumacząc termin dosłownie, powiedzieć można, że jest to stawianie męskości w centrum oraz organizowanie struktur społecz- 
nych na jej zasadach. Bourdieu zwraca uwage na związany z tym pojęciem aspekt nieświadomości, pokazując, że jednostka zdominowana (kobieta), nie zdając sobie z tego sprawy, przyjmuje w ocenie rzeczywistości perspektywę dominującego. Autor Meskiej dominacji pisze:

Jest paradoksem, że praktyczne schematy androcentryzmu, które leżą u podstaw społecznego konstruowania i postrzegania widocznych różnic ciała męskiego i kobiecego, stają się zarazem najdoskonalszą gwarancją nadawania znaczeń i wartości - nie podlegających dyskusji, a pozostajacych w zgodzie z podstawowymi zasadami androcentryzmu. To nie fallus (lub jego brak) jest fundamentem tej wizji świata, lecz przeciwnie - to owa wizja świata, zorganizowana wokół zasady pozostających we wzajemnej relacji rodzajów: męskiego i żeńskiego, stwarza fallus, konstruując go jako symbol męskości - punkt honoru. (...) Wyjątkowa siła męskiej socjodycei pochodzi bowiem ze zdolności do połączenia dwóch procesów: uprawomocnienia relacji dominacji przez wpisanie jej w naturę biologiczna, która sama w sobie jest już znaturalizowaną konstrukcją społeczną (Bourdieu 2004, 33).

Jak wynika z przytoczonego fragmentu, istnienie męskości nie samo w sobie konstytuuje nierówność, ale czynią to relacje między płciami. Władza kreuje się również w homospołecznych relacjach mężczyzn (w których męskość realizuje się wobec samej męskości) ${ }^{1}$. W utworze Barbara jesz̨z̨e Gasz̨tołdowa żona pojawiają się praktyki, które utwierdzają androcentryczny porządek świata, a przejawiają się w kontekście działań kobiet względem innych kobiet, a także mężczyzn. Jako że wyparty ze sfery publicznej i wtrącony w rodzinna pierwiastek żeński nie może stworzyć własnej kreacyjnej społeczności (zob. Blüher 1999, 255), to jego działania realizują się jedynie w obrębie „niewidoczności”. Kobiety pojawiają się więc jako osoby działające z ukrycia, stosujące podstęp, intrygi oraz sztuczki w celu osiagnnięcia swoich zamierzeń.

Akcja dramatu Magnuszewskiego rozgrywa się wokół walki o władzę pomiędzy królową Boną a resztą szlachty polskiej w momencie, w którym król

1 Hans Blüher w Teorii meskiej spoteczności przedstawił dwa rodzaje organizacji życia społecznego, których głównym wyznacznikiem jest płeć. Teoria Blühera opiera się na założeniu, że mężczyźni tworzą w społeczeństwie pewnego rodzaju struktury, które mają element mistyczny i tajemniczy (w odróżnieniu od rodziny). Homospołeczne zbiorowości mężczyzn wytwarzają miejsce do „publicznej reprezentacji wspólnoty”, a to sprawia, że w zakresie ich możliwości pojawia się pierwszeństwo w społecznej organizacji życia. Szerzej na ten temat zob. Blüher 1999. 
Zygmunt I Stary zbliża się ku śmierci. Walka toczy się o wychowanie następcy króla - Zygmunta Augusta, którego Bona próbuje zniewieścić i odsunąć od spraw państwowych, aby móc go kontrolować, natomiast szlachta chce wzbudzić w Zygmuncie cechy męskie, aby ten mógł sprawnie rządzić państwem. Już streszczając główne wydarzenia utworu, można dostrzec różnice w postrzeganiu ról płciowych: jednostka bliższa modelowi kobiecemu łatwo poddaje się manipulacji, natomiast męskość związana jest z władza.

Ważnymi bohaterkami w tym kontekście są dwórki królowej Bony - Luzzi i Palli, które próbują uwieść młodego Zygmunta, a także Barbara Radziwiłłówna (żona Gasztołda, wojewody trockiego) i sama królowa Bona. Nierówności między płciami objawiają się w utworze poprzez kreację bohaterek - Luzzi i Palli są frywolnymi pannami dworskimi, dla których nie liczy się nic oprócz tańców, śpiewów i uwodzenia, natomiast Barbara stanowi wobec nich przeciwwagę, charakteryzuje się cechami takimi jak bezgraniczne oddanie mężowi oraz Bogu. Bona widzi w żonie Gasztołda zagrożenie dla władzy, dlatego za pomoca trucizny pozbawia ją życia. Przejawiają się w tym miejscu typowe dla męskości elementy walki o władzę, ale w tym przypadku realizowane zza kulis i potajemnie. W utworze postawy bohaterów męskich sa gloryfikowane i uważane za honorowe, cnotliwe oraz ważne z perspektywy państwa (przykładem jest Gasztołd, mężczyzna niejako modelowy), o czym będzie jeszcze mowa.

\section{LUZZI}

$[\ldots \ldots \ldots \ldots \ldots \ldots \ldots \ldots \ldots \ldots \ldots \ldots \ldots \ldots$

Dla głowy Luzzi; przeglądam się w niej

Jak ma Wenecja w morzu, w którym wzrosła,

A ty Zygmuncie, czy się z Luzzi śmiej

Czy lubuj ją, byle Luzzi żyła

W pamięci wam, jak ci z dawna była

Rówienną boku, źrenicy, zabawy

(Magnuszewski 1877, 126)

Fragment, z którego wiele możemy dowiedzieć się na temat Luzzi, obfituje w odniesienia do młodości, radości, zabawy i uciech. Realizuje się w tym miejscu konstrukcja kobiecości niezaangażowanej w politykę, a zachowanie takie traktowane jest niepoważnie i uznawane przez szlachtę za szkodliwe. W tym miejscu należy wspomnieć, że wyraźnie zaznacza się tu, przewijający się w twórczości Magnuszewskiego w ogóle, aspekt walki swojskości z cu- 
dzoziemszczyzna. Głównym celem ataku nie jest kobiecość sama w sobie, ale włoskie wzorce kobiecości, które, poprzez wpływ Bony i włoskiego dworu, w pewien sposób deprawuja polskie wartości ważne z patriotycznej perspektywy autora - cnotę i honor. W kontekście płci dostrzegam tu jednak ukryty strach przed modelem kobiety bardziej niezależnej niż w przypadku Polek. Magnuszewski, gloryfikując Barbarę i jej postawę, popierał silnie patriarchalny model ról płciowych, w czym objawia się androcentryczna nieświadomość. Jak czytamy u Marii Boguckiej:

Krajem, gdzie działały liczne aktywne politycznie kobiety, były Włochy. Wśród nich specjalną sławę zdobyła Bianka Maria, żona księcia Franciszka Sforzy, zwana diva virago. Towarzyszyła ona mężowi w licznych wyprawach wojennych, czasem sama dowodziła oddziałami wojskowymi, między innymi kierowała obroną Cremony przed Wenecjanami w latach 1447-1448. Inna słynna virago to tzw. Madonna z Forli, Katarzyna Sforza, która w 1484 r. - wykorzystując zgon papieża Sykstusa IV - zajęła zamek św. Anioła i trzymała go tak długo, aż zdumieni i wściekli kardynałowie zdecydowali się okupić jej mężowi, Hieronimowi Rirario (Bogucka 2005, 62).

Historia pokazuje, że włoski ród Sforza może się poszczycić wieloma silnymi i wpływowymi postaciami kobiecymi, wśród których można wymienić także występującą w dramacie Bonę. Warto w tym miejscu rozwinąć znaczenie pojęcia diva virago. Jerzy Besala, opisując dzieje uczuć kobiet i mężczyzn, w kontekście Włoszek piętnastego i szesnastego wieku pisze:

Pojawiła się na scenie włoskiej postać dotąd nieznana - diva virago. Termin diva virago napotykamy w Wulgacie, Biblii przetłumaczonej przez św. Hieronima na przełomie IV i $\mathrm{V}$ wieku na łacinę z hebrajskiego i greki. W Wulgacie Adam, zafascynowany pojawieniem się nowej osoby obok, mówi w Księdze Rodzaju, po łacinie tym razem: Dixitque Adam hoc nunc os ex ossibus meis et caro de carne mea haec vocabitur virago quoniam de viro sumpta est. (I rzekł Adam: „Oto teraz jest kością z moich kości i ciałem z mego ciała i dlatego zostanie nazwana virago, bo z mężczyzny jest").

Nazwa virago pochodziła zatem od łacińskiego vir: „mąż”, „męski” (Besala 2014, 16).

Przytoczony fragment wskazuje, że włoskie kobiety zaczęły w XV wieku przejmować cechy przypisywane mężczyznom, takie jak waleczność, odwaga, honor (należy zaznaczyć, że do polityki mogły aspirować tylko kobiety 
wysoko urodzone), co bardzo dobrze obrazuje problem androcentrycznej nieświadomości, ponieważ zakłada, że silna kobiecość jest w pewnym sensie odłamem męskości, jej cząstką. W twórczości Magnuszewskiego być może objawia się pewnego rodzaju strach przed fenomenem virago, mogącym zakłócić porządek, w którym jednostką dominującą jest mężczyzna. Włoszki przedstawiane są jednoznacznie jako osoby mające negatywny wpływ na politykę i na samych mężczyzn. W Barbarže przedstawiono niezwykły proces, zgodnie z którym kobiety przyjmujące wartości męskie są deprecjonowane, tak samo jak mężczyźni charakteryzujący się cechami kobiecymi. Ten problem obrazuje dobrze scena z Zygmuntem Augustem oraz naśmiewającym się z niego Stańczykiem, który przebiera się za kobietę i mówi:

\section{STAŃCZYK}

I to nie dziwy...

Żeby było na męża w tym gmachu przystać!

Trza spódnicy w brokadzie by się ku wam dostać;

Dmuchać z włoska na ucho, palcem leść po drutach,

By szukać serca, co się schowało gdzieś w nutach...

(Magnuszewski 1877, 131)

Stańczyk w symbolice polskiej oznacza zatroskany o swój kraj głos rozwagi. Właśnie literatura doby romantyzmu na nowo odkryła postać błazna, który odznaczał się patriotyzmem oraz „obnażaniem brudnych stron społeczeństwa” (Słowiński 1993, 133) poprzez wyśmiewanie ich. Podobną strategię stosuje Magnuszewski. Biorąc pod uwagę reprezentatywną symbolikę Stańczyka w przedstawionym wyżej kontekście, można stwierdzić, że błazen uznaje za właściwy porządek rzeczy typowe role męskie i żeńskie - i w ten sposób umacnia istniejące już i zakorzenione w polskiej kulturze podziały. Wynika z tego, że jest to struktura uważana za właściwą dla prawidłowego funkcjonowania państwa.

Aby zaprezentować objawiający się w utworze zespół cech i ról przypisywanych kobietom w polskim środowisku, utrwalających jednocześnie władzę męska, należy zacytować Gasztołda, który zwraca się do Montiego, włoskiego lekarza:

GASZTOŁD (nagle z łoża się podniósł)

Strudzi? To nasza żona, to żony powinność, Modlić, kiedy mąż cierpi, żony - męża czynność 
W polu kordem i głowa, bo w tem męskość leży;

A białogłowa u nas to przy boku bieży

W złej dobie koić bole, usługa, kolanem.

Mąż u nas nie gitarą żonie, ale panem,

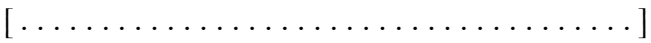

(z groźba)

A wy nie szepcie dziewom naszym swą zawiłość,

Owe włoskie uczucia, ową gładką miłość;

Bo wam, gdy kordów zbywa, nie wiecie jak użyć

Czasu, a więc niewiastom chcecie jakoś służyć,

Niby pacholę panu - My kochamy twardo,

Ale z serca, ale tak całe duszą hardą,

Że gdyby nam ją zabrał los, co nie daj Boże!

(Barbara całuje go w rękę).

Płakaćby nas nie stało, ale umrzeć - może

(Magnuszewski 1877, 142)

Pod pozorem idealizacji miłości, opartej na równości dusz, słowa Gasztołda pokazują konkretne role męskie, odnoszące się do panowania nad żoną (jest jej panem) oraz prowadzenia wojny (krew i walka sa silnie akcentowane jako męskie). Z kolei zajęcia kobiety są bardzo ograniczone i odnoszą się do służenia mężowi, modlitw i cierpienia. W historii przekonanie o niższości kobiet pojawia się często, ponieważ „ludzie odrodzenia dużo mówią o ideale żony, ale milczą o ideale męża. Jest to założenie a priori: mężczyzna jest doskonalszy od kobiety, nie trzeba go poprawiać, któźby zreszta śmiał, ponad nimi już tylko Bóg...” (Sztobryn 2000, 61). Zbliżony model rozumienia ról społecznych przedstawia mąż Barbary. Nie tylko słowa Gasztołda umacniają przejawiające się $\mathrm{w}$ dramacie przekonanie o słuszności tych ról i potrzebie ich realizacji. W epilogu umierająca z ręki Bony Radziwiłłówna doznaje objawienia, w którym anioły wraz z Maryja zabieraja ja do nieba. Barbara umiera, a Bona utwierdza swoją władzę nad Zygmuntem:

BONA (z całą dumą wstaje z królewskiego siedzenia, do osłupiałego Augusta, wskazując na Barbarę)

Cóż to, że ktoś zasłabnie, (wskazując na scenę dialogu)

To się wolno dla matki zapomnieć synowi?

O! nie - Syn chociaż królem, niech zna matki władzę! 
Kobiety, nie mogąc brać udziału w życiu publicznym (w dramacie wyjątkiem jest królowa Bona), muszą stosować różnego rodzaju podstępy, aby osiagać swoje cele. Interesujące są atrybuty przynależne Luzzi i Palli, a odnoszące się do sfery ukrytej i związane z androcentryzmem. Przykładowo, gdy do komnaty wchodzi Stańczyk w stroju kobiecym, gotowa na wszystko Palli sięga „do łona po rękojeść kobiecego sztyletu” (Magnuszewski 1877, 129), który symbolizuje męskość (Bourdieu 2004, 37). Podobnie Bona zdobywa władzę poprzez otrucie Barbary. Pokazuje w ten sposób, że nie można jej się sprzeciwiać, a śmierć Radziwiłłówny jest swego rodzaju karą dla Zygmunta Augusta za przeciwstawienie się matce. Kara w dramacie jest przedłużeniem patriarchalnego modelu kultury, ustanowionego symbolicznie w poprzednim utworze cyklu Magnuszewskiego, a konkretnie w Krwanym Chrzcie roku 1074. Dzieje się to po części poprzez nieświadome przejmowanie męskich wzorców zachowań przez kobiety występujące w dramacie.

Z badań etnograficznych wynika, że sfera aktywności męskich opiera się na tym, co zewnętrzne i publiczne, a czyny męskie są spektakularne i niebezpieczne (charakterystyczną przestrzenią aktywności mężczyzn jest wojna). Kobiety natomiast wiązane sa ze sfera „ukryta”, prywatna, ale ich działania cechują się monotonią i upokorzeniem, takie jak wychowywanie dzieci i praca w ogrodzie (Bourdieu 2004, 42). W czynach kobiet występujących w dramacie Magnuszewskiego znajdują się wspomniane elementy spektakularności działań, walki (intrygi, manipulacje), ale urzeczywistniają się one w sferze ukrytej, co jest znamienne dla mieszania się porządków męskiego i żeńskiego, o których piszę. Urzeczywistnia się $\mathrm{w}$ ten sposób kobiecość virago, nieświadomie przejmująca i realizująca męskie wzorce, a także - w połączeniu z przywiązaniem kobiet do sfery prywatnej - utwierdzająca stereotyp kobiety intrygantki.

Jak wynika z omawianego przeze mnie problemu, androcentryczna nieświadomość objawia się w ujmowaniu postaw i działań uważanych za męskie w sferze władzy i polityki (nawet jeśli podejmują je kobiety) w sposób, który nie wymaga legitymizacji. Damy zbliżające się do modelu męskiego są odrzucane i uważane za zagrożenie, ponieważ w pewien sposób zakłócają męski porządek. Kobiecość jest silnie gloryfikowana tylko w relacji podrzędności i uległości. Wraz z rozwojem historii rośnie rola kobiet w kształtowaniu społeczeństwa, co daje im nadzieję na zmianę sytuacji i statusu społecznego, lecz androcentryczna percepcja ciagle sytuuje kobiecość w sferze podrzędności. Bona w celu przejęcia kontroli nad synem wykorzystuje te same sposoby narzucania władzy, które charakteryzuja patriarchat, utrwalając społecznie przyjęty androcentryczny porządek świata. 
Czas przyjrzeć się kreacji młodego króla Zygmunta Augusta w kontekście jego męskości zestawionej z ogólnie przyjętymi, istniejącymi w kulturze normami. Istotny jest sposób, w jaki zniewieściałość wpływa na postrzeganie przez społeczeństwo ról męskich i żeńskich oraz to, w jaki sposób sytuują się one względem siebie.

Bourdieu, pisząc o manifestującej się podrzędności i nadrzędności w stosunku seksualnym, zwraca uwagę na pasywną pozycję kobiety i aktywna mężczyzny. Erotyzacja związku dominacji przejawia się poprzez męskie pragnienie posiadania oraz żeńskie pragnienie męskiej dominacji (Bourdieu 2004, 31). Badacz zwraca również uwagę, że władza lepiej widoczna jest w akcie homoseksualnym, ponieważ:

w wielu społecznościach stosunek homoseksualny (i homoseksualne „posiadanie”) jest pojmowany jako wyraz „mocy”: akt dominacji afirmujący wyższość poprzez „ukobiecenie” podległego. Na przykład u Greków ten, który podlegał owej dominacji, narażał się na utratę honoru oraz utratę statusu prawdziwego mężczyzny i obywatela (Bourdieu 2004, 32).

Przyjmowanie przez mężczyzn ról nadanych kulturowo kobietom doprowadza do degradacji ich statusu określanego jako „prawdziwa męskość”. Oprócz przejawiającego się w powyższym fragmencie problemu „ukobiecania”, warto zwrócić uwage na aspekt społeczny, który organizowany jest przez życie seksualne. Męskość zniewieściała odnosi się nie tylko do problemu dewaluacji wartości takich jak honor, cnota i odwaga, ale także do zmiany realnie pojmowanej pozycji w społeczeństwie, co przejawia się poprzez utratę statusu obywatela. Odniesienie do starożytnej Grecji jest w tym kontekście bardzo trafne, ponieważ kultura europejska mocno czerpie z wpływów, jakie wywarł na nią antyk i pewne pozostałości po nim można odnaleźć chociażby w spuściźnie objawiającej się we wzajemnych relacjach mężczyzn i kobiet:

Grecja klasyczna, czasów Peryklesa, to kraj niechętny kobietom. Są one, zwłaszcza w Atenach, zamknięte w domu, sprowadzone do roli żony i matki; ich głównymi cnotami ma być posłuszeństwo i rodzenie dzieci. Uczestnictwo w życiu publicznym jest ograniczone do niesienia kwiatów w procesjach religijnych. (...)

Grecy traktowali kobiety z lekceważeniem, jako istoty naiwne i ciekawskie, co mogło powodować różne nieszczęścia. Pandora otwierająca mimo zakazu puszkę, podobnie lekkomyślna jak Ewa zrywająca jabłko, 
Psyche narusza wydany jej zakaz spojrzenia w twarz Amora. Takie istoty musiały być poddane stałej kontroli mężczyzny - ojca, męża, brata. Najwięksi greccy filozofowie, Platon i Arystoteles, uważali kobiety za stworzenia niższej kategorii, wręcz ukształtowane z innej niż mężczyźni materii (Bogucka 2005, 24).

Zestawiając status kobiet żyjących w starożytnej Grecji z relacjami damsko-męskimi przedstawionymi w dramacie Magnuszewskiego, wyodrębnić można zestaw cech kobiecych bliskich antycznemu wzorcowi, a są to: serwilizm, zamknięcie w przestrzeni prywatnej, ciagła kontrola, niższość. Ukształtowany w ten sposób model kobiecości utrzymuje się w historii kultury europejskiej przez wiele stuleci i objawia się w jej wytworach. Cytowany fragment jest pomocny w analizie męskości Zygmunta Augusta. Królewicz staje się zniewieściały pod wpływem Włoszek Luzzi i Palli, przez co jest niezdolny do kierowania państwem, traci honor w oczach innych arystokratów i szlachciców, a także jest podatny na kontrolę i manipulacje. Zniewieściały mężczyzna nie budzi strachu, tak jak diva virago, ale co najwyżej wywołuje politowanie, z czego naśmiewa się Stańczyk, przebierając się w damskie ubrania. Krótko mówiąc, wzorce męskości są silnie zakorzenione w kulturze, a ich przełamanie niesie poważne konsekwencje społeczne, niezależnie od stanu, jaki dana jednostka reprezentuje. Męskość zniewieściała jest skazana na ostracyzm i degradację społeczną.

Sam Zygmunt August zwraca uwagę na swoje rozdarcie pomiędzy patriotycznym obowiązkiem, kojarzonym z męskością, a kobiecymi zabawami:

Z. AUGUST (słychać głośniej muzykę)

$[\ldots \ldots \ldots \ldots \ldots \ldots \ldots \ldots \ldots \ldots \ldots \ldots \ldots$

Nie wiem co cięży, co mi piersi studzi?

Ale mam w to, że to dwojga ludzi

Gra we mnie język i krew:

Matki krew - wenecki śpiew -

Ojca krew - polski kord -

Z gardła wrzask, w polu mord.

(Magnuszewski 1877, 126)

W Zygmuncie odzywają się pierwiastki ojcowski i matczyny, reprezentujące jasne podziały na męskość i kobiecość, o których była już mowa w tym artykule. Trudna sytuacja, w której znalazł się August, wynika z niemożności sprzeciwienia się którejkolwiek ze stron. Odwrócenie się od matki spotkało 
się w końcu z kara, w postaci otrucia Barbary, natomiast odejście od ojca oznaczałoby skazę na honorze i niewywiązanie się z patriotycznego obowiązku (w znaczeniu dziewiętnastowiecznym). Stańczyk mówi do Zygmunta:

Może gdy krew pocieknie w męstwie się polubisz, Jak dziedzic, syn mojego króla Polski, Litwy,

Żmudzi i Ukrainy! Może cię na bitwy

Spędzi krew błazna - i Wołosz wyczubisz!

O! tnij mnie królewicu! Bo łacniej błaznowi

Poddać kark, jak uragać ojcu i królowi.

(Magnuszewski 1877, 131)

Model męskości, do którego Zygmunt powinien dążyć, reprezentuje prawdziwy patriota - Gasztołd. Mężczyźni różnią się od siebie nie tylko zachowaniem, ale na kontrast wskazuje także wystrój pomieszczeń, w których się znajduja. Młody królewicz przebywa w pokoju z karmazynowymi zasłonami, a w sali obok weselą się i tańczą inni ludzie. August ubrany jest w czarny strój hiszpański z ostrogami. W komnacie Gasztołda z kolei pojawiają się przedmioty związane z męskościa: niedźwiedzia skóra na łożu i zbroja rycerska przy ścianie. Szlachcic ubrany jest w skórzany kaftan. Objawiają się w tym miejscu różnice w kreacji bohaterów, które jasno przedstawiają Zygmunta jako osobę będąca pod wpływem zagranicznej mody, natomiast umierający wojewoda trocki reprezentuje pożądane przez polską szlachtę wartości, takie jak waleczność i odwaga. Przejawia się tu dominacja nie tylko nad kobiecością (obok łóżka klęczy jego żona), ale także nad naturą, na co wskazuje niedźwiedzia skóra. Wzorzec mężczyzny odnoszący się do wartości tradycyjnych utwierdza go w roli władcy absolutnego. Zniewieścienie Zygmunta Augusta sprawia, że pośród arystokratów i szlachciców pojawiają się głosy sprzeciwu wobec młodego króla. Książę Radziwiłł, zwany Czarnym, kuzyn Barbary, zwraca uwage na złe wychowanie Zygmunta i jego przywiązanie do matki, co ma zgubny wpływ na państwo i jego losy (Magnuszewski 1877, 150).

Zniewieściałość realizuje się w kontekście relacji płci, dlatego uważana jest za niższą formę męskości. Wracając jeszcze na chwilę do starożytnej Grecji, warto przypomnieć, że Arystoteles uważał, iż kobieta jest „nieudanym mężczyzną" (Bogucka 2005, 25). Ponownie wskazuję na postrzeganie ról płciowych poprzez perspektywę androcentryczną, ponieważ kobiecość jawi się w relacji do męskości idealnej - wszystkie inne wahania wokół paradygmatu, odchylenia od normy, są traktowane jako męskość gorszej wartości. Kobieta 
czerpiąca ze spektrum cech uznanych za męskie jest postrzegana jako zagrożenie dla porządku, natomiast mężczyzna przypominający swoim wyglądem i zachowaniem kobietę jest wystawiony na pośmiewisko i skazany na odrzucenie. Traci wszelkie atrybuty mogące włączyć go w przestrzeń publiczna, stając się niezdolnym do dominowania.

Krystyna Kłosińska w artykule Zagrożona meskośc / zagrożone meskości odnosi się do pojęcia virilité, które ,jest zbiorem nakazów skierowanym głównie do mężczyzn” (Kłosińska 2018, 193) i oznacza męskość mającą funkcję porządkującą społeczeństwo. Virilité bezustannie manifestuje się w czynach mężczyzny, które odznaczają się takimi wartościami, jak godność, siła, honor, a realizuje się w wojnie, podbojach, panowaniu nad naturą i ma silny związek ze śmiercią. Jest to zjawisko, którego największy rozkwit przypada na wiek dziewiętnasty. Pojmując virilité w kategoriach opisanych wyżej i tych występujących w dramacie Magnuszewskiego, można stwierdzić, że autor pokazał sytuację przełamywania tego kodu. Męskość, która nie przestrzega esencjonalnych nakazów i pozbawiona jest zwyczajowej manifestacji, skazana zostaje na niepowodzenie, czego przykładem jest Zygmunt August. Dopiero miłość do Barbary daje mu siły, aby przejać się losami państwa, stać się „prawdziwym mężczyzną”, za co zostaje ukarany przez Bonę. Dopiero przestrzeganie zasad realizowania się męskości organizuje społeczeństwo w strukturze patriarchalnej, dlatego ochrona tradycyjnych wartości jest tak ważna dla męskich bohaterów stanowiących większość (arystokracja i szlachta). Ze względu na przejęcie perspektywy grupy dominującej, kobiety nie sa w stanie przeciwstawić się temu porządkowi, co więcej, podejmują działania podtrzymujące go.

Przedstawiona tu analiza prowadzi do wniosku, że w pierwszej połowie dziewiętnastego wieku wciąż istnieją silnie zakorzenione podziały na role płciowe oraz obowiązuje konkretny status kobiety i mężczyzny realizowany w społeczeństwie. Mimo zmiany w perspektywie opisywania losów kobiet w utworach literackich (która może być uznana za zjawisko pozytywne), czego przykładem jest chociażby twórczość Magnuszewskiego czy znana szerzej Grą̇yna Mickiewicza, postrzeganie kobiecości przez mężczyzn jest ciagle silnie wartościowane negatywnie. W twórczości literackiej opisywanego okresu można odnaleźć ciagle żywe, funkcjonujące od pokoleń ślady nierówności płciowych, które stały się elementem nieświadomej androcentrycznej percepcji świata. Przykładami takiego myślenia są obecne w tekście Magnuszewskiego kreacje bohaterów, wykraczające poza ogólnie przyjęte normy. Bourdieu w Meskiej dominacji twierdzi, że porządek społeczny kon- 
struowany jest przez wyraźne podziały, dwa różne habitusy. Dzieło Magnuszewskiego jest o tyle interesujące, że przedstawia mieszanie się tych porządków, co pozwala pokazać, w jaki sposób kultura patriarchalna redukuje kobiecość do cech stereotypowo uznawanych za kobiece, a męskość do cech męskich, nie pozwalając na wykroczenia $z$ funkcjonującego paradygmatu.

Tak jak Bona, reprezentująca typ diva virago, nie może istnieć w przestrzeni męskiej, tak zniewieściały Zygmunt jest odrzucany przez męską społeczność, ponieważ obie kreacje opierają się na mieszaniu porządków. Z drugiej strony Barbara i Gasztołd reprezentują wartości oparte na silnych podziałach - mężczyzna i kobieta mają jasno określone role, które muszą odgrywać. Model oparty na nierównościach utrzymuje się, ponieważ w historii zaistniała zmiana w rozumieniu tego, co naturalne. Według Bourdieu nastapił proces uspołeczniania tego, co biologiczne i biologizacji tego, co społeczne (Bourdieu 2004, 10), a to oznacza, że pewne pojęcia i role społeczne uznawane dziś za naturalne tak naprawdę są historyczne, ale i mocno zakorzenione w kulturze. Dlatego role męskiej kobiety czy kobiecego mężczyzny uznawane są za „nienaturalne”, przez co wartościowane są negatywnie. Mechanizm odrzucenia inności sprawia, że struktury patriarchalne mogą ciagle istnieć i ciagle realizować się w kulturze. Poprzez androcentryczną nieświadomość cementują się społecznie akceptowalne wartości, które same przez się utwierdzają męski punkt widzenia rzeczywistości, co podtrzymuje istnienie patriarchatu. Występowanie tych mechanizmów w dramacie Magnuszewskiego Barbara jeszcze Gas z̧ołdowa żona jest potwierdzeniem przejawiającego się w cyklu Niewiasta polska kształtowania się społeczeństwa opartego na modelu patriarchalnym.

\section{Bibliografia}

Besala J., 2014, Mitość i strach. Drieje uczuć kobiet i mę̇çyyzn, t. 4, Poznań.

Blüher H., 1999, Teoria męskiej społeczności, przeł. Gabiś T., w: Rewolucja konserwatywna w Niemczech 1918-1933, wyb. i oprac. Kunicki W., Poznań.

Bogucka M., 2005, Gorsza pté́, Warszawa.

Bourdieu P., 2004, Męska dominacja, przeł. Kopciewicz L., Warszawa.

Kłosińska K., 2018, Zagrożona męskość/ Zagrożone meskości, w: Formy męskości 1, Dziadek A., Mazurkiewicz F., red., Warszawa.

Magnuszewski D., 1877, Niewiasta polska w trzech wiekach w: Drieła Dominika Magnuszewskiego $w$ trzech tomach, t. 1, Lwów.

Ruszczyńska M., 1995, Dominike Magnuszenski. Między historiq i natura, Zielona Góra.

Słowiński M, 1993, Błazen: dzieje postaci i motywu, Warszawa. 
Sztobryn S., 2000, Status kobiety w (meskiej) myśli pedagogicznej. Przeglad stronniczo wybranych stanowisk, w: Jakubiak K., red., Partnerka, matka, opiekunka. Status kobiety w dziejach nowożytnych od XVI do XX wieku, Bydgoszcz.

Wojciech Lemański - mgr, Instytut Literaturoznawstwa, Uniwersytet Śląski w Katowicach, Katowice, Polska.

Magister filologii polskiej Uniwersytetu Śląskiego w Katowicach. Zainteresowania naukowe: literatura romantyzmu, feminizm, gender studies.

Kontakt: lemanski.wojciech1@gmail.com 